ORIGINAL ARTICLE

\title{
Grafting among species of the genus Handroanthus (Bignoniaceae)
}

\author{
Enxertia entre espécies do gênero Handroanthus (Bignoniaceae)
}

Ingridh Medeiros Simões ${ }^{1}$ (ㄷ, Rodrigo Sobreira Alexandre ${ }^{1}$ (i), Thuanny Lins Monteiro Rosa ${ }^{1}$ (i),

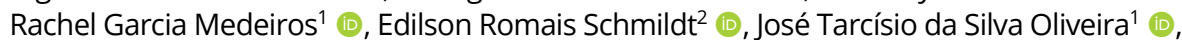
José Carlos Lopes ${ }^{3}$ (D) João Paulo Bestete de Oliveira ${ }^{4}$ (D), Adésio Ferreira ${ }^{3}$ (D), Wagner Campos Otoni ${ }^{5}$ (b)

${ }^{1}$ Universidade Federal do Espírito Santo - UFES, Jerônimo Monteiro, ES, Brasil

${ }^{2}$ Universidade Federal do Espírito Santos - UFES, São Mateus, ES, Brasil

${ }^{3}$ Universidade Federal do Espírito Santo - UFES, Alegre, ES, Brasil

${ }^{4}$ Instituto Federal do Espírito Santo - IFES, Alegre, ES, Brasil

${ }^{5}$ Universidade Federal de Viçosa - UFV, Viçosa, MG, Brasil

How to cite: Simões, I. M., Alexandre, R. S., Rosa, T. L. M., Medeiros, R. G., Schmildt, E. R., Oliveira, J. T. S., Lopes, J. C., Oliveira, J. P. B., Ferreira, A., \& Otoni, W. C. (2021). Grafting among species of the genus Handroanthus (Bignoniaceae). Scientia Forestalis, 49(130), e3513. https://doi.org/10.18671/scifor.v49n130.12

\begin{abstract}
The trees of the genus Handroanthus have an unmistakable ornamental beauty, which despite the short flowering period, ennoble the landscape, in addition to the high ecological, medicinal value and quality wood production. The aim of this work was to analyze the compatibility of top cleft grafting among the species Handroanthus chrysotrichus (Hc), Handroanthus heptaphyllus $(H h)$ and Handroanthus roseo-albus (Hr-a). Treatments were constituted by different scion/rootstock combinations: $\mathrm{Hc} / \mathrm{Hc} ; \mathrm{Hc} / \mathrm{Hr}-\mathrm{a} ; \mathrm{Hc} / \mathrm{Hh} ; \mathrm{Hr}-\mathrm{a} / \mathrm{Hc}$; $\mathrm{Hr}$-a/Hr-a; $\mathrm{Hr}-\mathrm{a} / \mathrm{Hh} ; \mathrm{Hh} / \mathrm{Hc} ; \mathrm{Hh} / \mathrm{Hr}$ - $\mathrm{a} ; \mathrm{Hh} / \mathrm{Hh}$. The high compatibility of $\mathrm{Hh}$ self-grafting (83.3\%) was identified by means of a well-established vascular connection, as well as the similarity of gas exchange values compared to the ungrafted seedlings. The combinations $\mathrm{Hh} / \mathrm{Hc}(55.5 \%)$ and $\mathrm{Hr}-\mathrm{a} / \mathrm{Hr}-\mathrm{a}(38.8 \%), \mathrm{Hc} / \mathrm{Hc}(33.3 \%)$ and $\mathrm{Hh} / \mathrm{Hr}-\mathrm{a}$ (27.7\%), in decreasing order, have potential to increase grafting success. In this sense, future works must be elaborated to improve the efficiency in graft taking and that allows, for example, the production of branches with different colors of flowers in the same canopy of a tree in the Handroanthus genus.
\end{abstract}

Keywords: Handroanthus spp.; Ipês; Vegetative propagation; Cleft grafting; Physiology; Anatomy.

\section{Resumo}

Os ipês apresentam uma beleza ornamental inconfundível, que apesar do curto período de florescimento, enobrecem a paisagem, além do elevado valor ecológico, medicinal e produção de madeira de qualidade. Objetivou-se com este trabalho analisar a compatibilidade da enxertia na modalidade garfagem no topo em fenda cheia entre as espécies Handroanthus chrysotrichus (Hc), Handroanthus heptaphyllus (Hh) e Handroanthus roseo-albus ( $\mathrm{Hr}-\mathrm{a}$ ). Os tratamentos foram constituídos pelas combinações de enxerto/porta-enxerto: $\mathrm{Hc} / \mathrm{Hc}$; $H c / H r-a ; H c / H h ; H r-a / H c ; H r-a / H r-a ; H r-a / H h ; H h / H c ; H h / H r-a ; H h / H h$. A alta compatibilidade da autoenxertia de ipê roxo (83,3\%) identificada por meio de uma conexão vascular bem estabelecida, bem como, a não alteração nos valores das trocas gasosas em comparação às mudas não enxertadas, resultou no florescimento precoce. Na combinação $H h / H c$ também verificou-se o florescimento do ipê roxo. As combinações $H h / H c(55,5 \%)$ e $H r-a / H r-a(38,8 \%), H c / H c(33,3 \%)$ e $H h / H r-a(27,7 \%)$ em ordem decrescente apresentam potencial para aumentar o pegamento. Neste sentido, trabalhos futuros devem ser elaborados para melhorar a eficiência no pegamento da enxertia e que permita, por exemplo, a produção de mudas com cores distintas na mesma copa do gênero Handroanthus.

Palavras-chave: Handroanthus spp.; Ipê; Propagação vegetativa; Garfagem; Fisiologia; Anatomia.

Financial support: To the National Council for Scientific and Technological Development (CNPq), for granting research scholarships to the first, second, fourth, sixth, seventh and ninth authors. To the Coordination for the Improvement of Higher Education Personnel (CAPES) for granting a research scholarship to the third author.

Conflict of interest: Nothing to declare.

Corresponding author: simoes.ingridh@gmail.com

Received: 11 November 2019.

Accepted: 14 May 2020.

Editor: Paulo Henrique Müller Silva.

(c) (i) This is an Open Access article distributed under the terms of the Creative Commons Attribution License, which permits unrestricted use, This is an Open Access article distributed under the terms of the Creative Commons Attrib
distribution, and reproduction in any medium, provided the original work is properly cited. 


\section{INTRODUCTION}

Brazil is recognized as a country with high biodiversity, however, many Brazilian cities have a large number of exotic trees in urban environments (Moro \& Castro, 2015). These authors verified that among 219 ornamental trees in the city of Fortaleza, Brazil, 158 were exotic and only 61 native. In Rio de Janeiro, out of 1701 sampled streets, 20 native and 40 exotic species were found. A high percentage of streets had no trees planted and the number of trees was higher in upper-class neighborhoods. The strong prevalence of exotic species is indicative of the negative impact of human activity on biota. As the municipality of Rio de Janeiro harbors forested areas, the risk of propagating exotic species is elevated (Santos et al., 2010).

Among the native forest species, those belonging to the Bignoniaceae family, represented by different species of the genus Handroanthus, present quite exuberant and colorful flowers, which gives them ornamental value beyond the geographic distribution (Jardim Botânico do Rio de Janeiro, 2020), as well as size compatible with urban afforestation (Backes et al., 2011). Moreover, the wood of this genus has a high commercial value which is an economic reason for afforestation. In the Amazon area, there is a record of "misidentification" (naming other species as ipê and inflating the diameter of the tree), so that the extra volume of ipês is easily used to conceal illegal ipês (Brancalion et al., 2018). According to these authors, this may be a complementary strategy to generate a "surplus" of licensed timber from logging, which leads to the illegal legalization of timber from logging.

The species of Handroanthus are usually propagated by seeds, as in Handroanthus impetiginosus (Mart. ex DC.) Mattos (Martins et al., 2011; Lima et al., 2014). Nevertheless, some studies have shown that vegetative propagation by means of mini-cuttings of Handroanthus heptaphyllus (Mart.) Mattos (Oliveira et al., 2016) and even in in vitro cultivation of $H$. impetiginosus shoots (Jausoro et al., 2010) is feasible. Other vegetative propagation techniques are also important, such as grafting, which leads to adaptation to different types of soils and tolerance or resistance to diseases. However, grafting among different species enables whole nuclear genomes to be transferred to generate a new polyploid (allopolyploidization) species, as observed in Nicotiana tabauca-supera (Fuentes et al., 2014).

In forest species, grafting has contributed several advances, such as: rejuvenating adult individuals presenting advanced chronological age, in which mature propagules were grafted onto a juvenile rootstock (Wendling \& Xavier, 2001); increasing rubber production in Hevea brasiliensis (Cardinal et al., 2007); and preventing the attack of Hypsipyla grandella (Lepidoptera: Pyralidae), by using the grafting of the resistant species Khaya senegalensis and Toona ciliata on the sensitive species Cedrela odorata and Swietenia macrophylla (Perez et al., 2010). In the genus Handroanthus, the importance of the combination between different species in grafting is to allow early flowering and polychromatic canopies.

Considering the aforementioned, this work aimed to analyze the compatibility of grafting among different species of the genus Handroanthus.

\section{MATERIAL AND METHODS}

The experiment was conducted at the Forest Seed Laboratory and Forest Nursery of the Department of Forestry and Wood Sciences at the Center for Agricultural Sciences and Engineering, belonging to the Federal University of Espirito Santo, municipality of Jerônimo Monteiro, State of Espírito Santo, Brazil.

In the Forest Seed Laboratory, seeds of Handroanthus chrysotrichus (Mart. ex DC.) Mattos (Figure 1a), Handroanthus roseo-albus (Ridl.) Mattos (Figure 1b) and Handroanthus heptaphyllus (Mart.) Mattos (Figure 1c) (seed trees located in Alegre-ES, Figure 1d) were sown in plastic trays containing washed and sterilized $\left(100^{\circ} \mathrm{C}\right.$ for $\left.48 \mathrm{~h}\right)$ sand as substrate, 
and kept in BOD chamber set at $25^{\circ} \mathrm{C}$ and photoperiod of $8 \mathrm{~h}$. The sand was washed and sterilized at $100{ }^{\circ} \mathrm{C}$ for $48 \mathrm{~h}$ in aluminum trays. During emergence of the seedlings, sand was moistened with distilled water, when necessary.

When the seedlings of the three Handroanthus species reached five centimeters in height in the nursery, they were bare-root transplanted to containers of $3.4 \mathrm{I}$, containing the Bioplant ${ }^{\circledR}$ commercial substrate (pine bark and coconut fiber).

Rootstocks were grafted when the diameter of the root collar reached $7.0 \mathrm{~mm}$. The graft used was the top cleft type. In this case, rootstocks were decapitated to the height of $10 \mathrm{~cm}$ above the ground and then subjected to a vertical slit of approximately one centimeter in length. Subsequently, $7.0 \mathrm{~cm}$ long top cleft grafts (scions), removed from adult plants in the field, were subjected to two cuts at their base, in the form of a double bevel. The junction between the scion and the rootstock was performed by inserting the cleft into the rootstock slit so that both parts could match on at least one side. Then, the grafting region was wrapped with a latex elastic fastener, which in its normal condition without being distended, has the following dimensions: $L \times W=85 \times 2.3 \mathrm{~mm}$ and under pressure, that is, elongated, the dimensions were: $L \times W=370 \times 1.26 \mathrm{~mm}$, where $L$ is given by the length of the elastic fastener and $W$ by the width of the two parts joined. The grafted region was further covered with a plastic bag tied with a string at its lower edge to make a moist chamber, in order to avoid dehydration of the tissues.

The experimental design used in randomized blocks (RBD), with nine treatments and four replicates (Figure 1e) and each experimental unit consisted of 10 plants. The treatments were composed of different combinations of graft/rootstock, as: 1) $\mathrm{Hc} / \mathrm{Hc}$; 2) $\mathrm{Hc} / \mathrm{Hh}$; 3) $\mathrm{Hc} / \mathrm{Hr}$-a; 4) $\mathrm{Hh} / \mathrm{Hh}$; 5) $\mathrm{Hh} / \mathrm{Hc}$; 6) $\mathrm{Hh} / \mathrm{Hr}$-a; 7) $\mathrm{Hr}$-a/Hr-a; 8) $\mathrm{Hr}$-alHc; 9) $\mathrm{Hr}$-a/Hh where $\mathrm{Hc}$ corresponds to the species Handroanthus chrysotrichus; Hr-a to Handroanthus roseo-albus and $\mathrm{Hh}$ to Handroanthus heptaphyllus.

The characteristics analyzed were: grafting success (\%), scion bud number, scion bud length $(\mathrm{cm})$, scion diameter $(\mathrm{cm})$, rootstock diameter $(\mathrm{cm})$, grafted region diameter $(\mathrm{cm})$, at 60

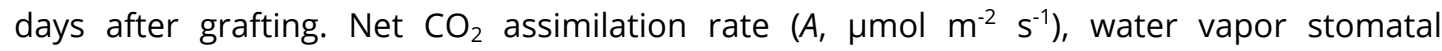

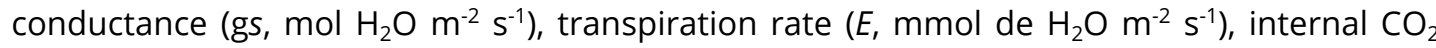

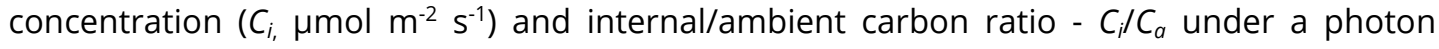
irradiance of $1000 \mu \mathrm{mol} \mathrm{m}^{-2} \mathrm{~s}^{-1}$, and ambient $\mathrm{CO}_{2}$ concentration $\left(C_{a}\right)$ of $400 \pm 8 \mu \mathrm{mol} \mathrm{CO}_{2} \mathrm{~mol}^{-1}$ were determined 120 days after grafting, with the aid of a portable infrared gas analyzer (IRGA, Li-Cor, model LI-6400, Nebraska, USA). Gas exchange evaluations were performed on mature fully expanded leaves and without pest attacks or abiotic lesions. Readings were performed between 9:00 am and 10:30 am, when $A$ was at its maximum value. The flowering of ungrafted and grafted plantlets of species of the genus Handroanthus was also evaluated 120 days after the experiment set up.

The anatomical sections were made in $20 \mu \mathrm{m}$ thick sections, in cross and tangential longitudinal planes, using a sliding microtome (Leica SM2000R), placed in a Petri dish with 60\% sodium hypochlorite, for one minute, for the bleaching of tissues. Subsequently, the material was washed in distilled water and dehydrated in ethyl alcohol for one minute, at the concentrations of $10 ; 20 ; 30 ; 50 ; 60 ; 70 ; 80 ; 90$ and $100 \%$. Then safranin stain was added and the sections were subjected to the following concentrations of alcohol and butyl acetate: $75-25 ; 50-50,25-75 ; 0-100 \%$, respectively. Once the provisional slides were mounted, glycerin and water were added to the slides (1:1), and images were taken using a stereoscopic microscope with coupled camera (BEL Photonics ${ }^{\circledR}$ ) in the Wood Sciences Lab. The anatomical evaluation was performed in the form of sampling, therefore no statistical analysis were done. 


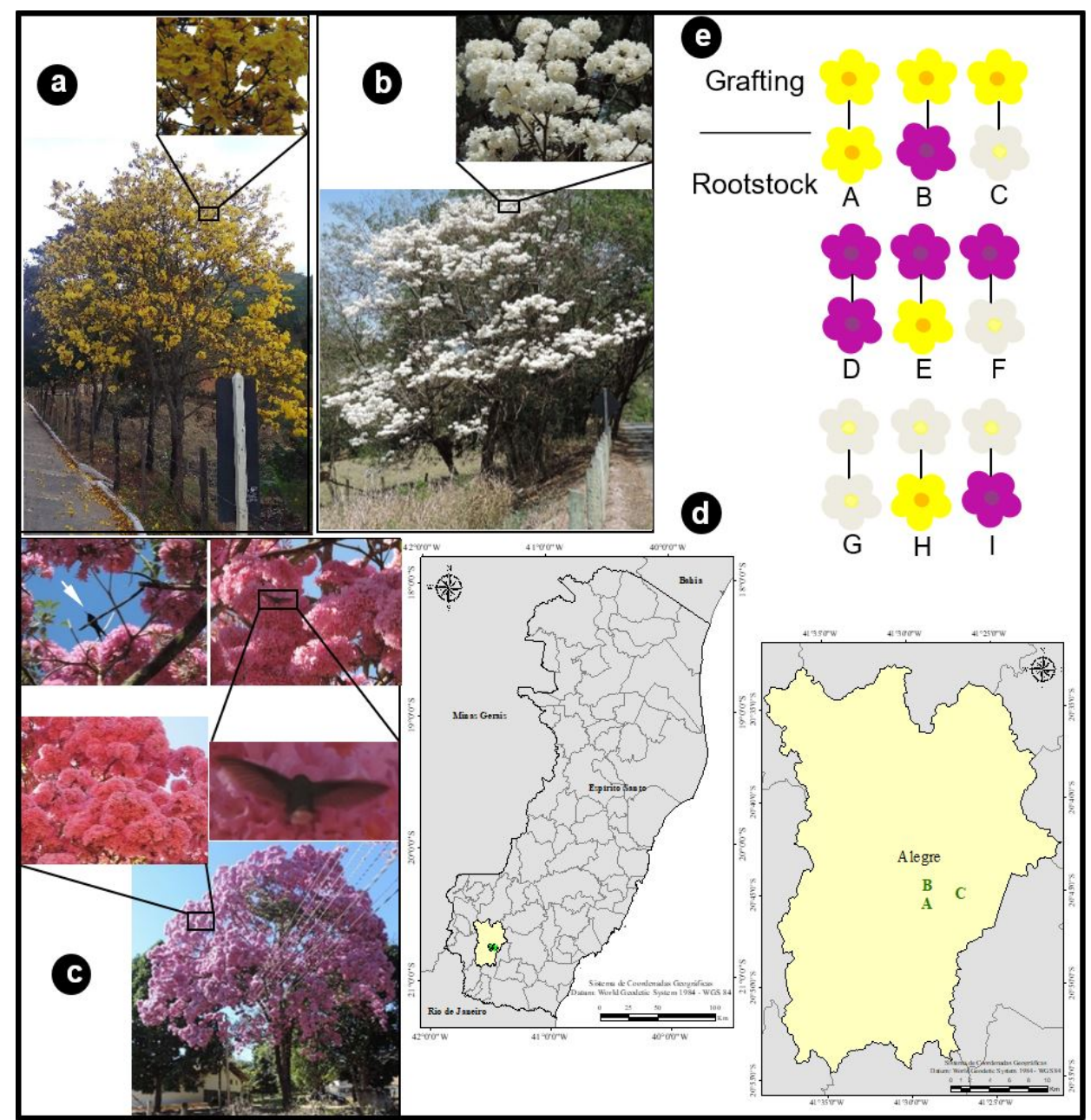

Figure 1. Spatial distribution of matrix plants of species of the genus Handroanthus. (a) Matrix plant and bouquet of $H$. chrysotrichus (Mart. ex DC.) Mattos - municipality of Alegre-ES. (b) Matrix plant and bouquet of $H$. roseo-albus (Ridl.) Mattos - municipality of Alegre-ES. (c) Matrix plant and bouquet of $H$. heptaphyllus (Mart.) Mattos - municipality of Alegre-ES (detail for the presence of pollinating agents such as the hummingbird - arrow and insects in the canopy of $H$. heptaphyllus adult plants), both undergoing flowering. (d) Spatial distribution of matrix plants of Handroanthus sp. e. Schematic drawing of the combination of cleft grafting of Handroanthus adult plants from the field into juvenile rootstocks, of seed origin. Scion/rootstock ratio: A. Hc/Hc (self-crafting); B. Hc/Hh; C. Hc/Hr-a; D. Hh/Hh (self-grafting); E. Hh/Hc; F. Hh/Hr-a; G. Hr-a/Hr-a (self-grafting); H. Hr-a/Hc; I. Hr-a/Hh. Abbreviations: $\mathrm{Hc}$ (H. chrysotrichus); $\mathrm{Hr}-\mathrm{a}$ (H. roseo-albus); Hh (H. heptaphyllus).

The insoluble lignin content (modified Klason method) of the scion seed plants of the Handroanthus species was determined according to the procedure described by Gomide \& Demuner (1986). The soluble lignin content (SLC) (modified Klason method) in sulfuric acid was measured via UV spectrophotometry using the equation described by Goldschmidt (1971) (Equation 1) and total lignin was obtained by the sum of soluble and insoluble lignins.

$\operatorname{SLC}(\%)=\frac{(4.53 \times \mathrm{A} 215)-\mathrm{A} 280}{300 \times \mathrm{W}} \times 100$

Where $A_{215}$ is the Absorbance of the filtrate at $215 \mathrm{~nm} ; A_{280}$ is the Absorbance of the filtrate at $280 \mathrm{~nm}$; W is the wood sample weight in grams.

The basic density of samples (core sampling) was determined according to the Brazilian Regulatory Standards - NBR 11941 of the Brazilian Association of Technical Standards - ABNT (Associação Brasileira de Normas Técnicas, 2003). 
In order to determine the age of the scion donor trees, core samples were collected by means of a non-destructive method with the aid of a $5 \mathrm{~mm}$ internal diameter increment borer (Presler Probe). Core samples were fixed in wood support using white glue, increasing stability in the grinding process. The evaluation was performed visually using magnifying glass (10x), without imaging programs.

The data were submitted to analysis of variance and the means were compared by the Scott-Knott test for grouping means, at a 5\% probability level, by the Genes software (Cruz, 2016).

\section{RESULTS AND DISCUSSION}

The $H$ h/Hh self-graft combination resulted in the highest rate (83.3\%) of successful union between scion and rootstock [or has a well-established vascular connection between scion and rootstock rate] (Table 1), different from the $\mathrm{Hc} / \mathrm{Hc}$ and $\mathrm{Hr}$ - $a / \mathrm{Hr}$ - $a$ with low grafting success of 33.3 and $38.8 \%$, respectively. Interspecific scion/rootstock combinations of the genus Handroanthus resulted in medium (Hh/Hc: 55.5\%), low (Hh/Hr-a: 27.7\%; Hc/Hh, $\mathrm{Hc} / \mathrm{Hr}-\mathrm{a}$ and $\mathrm{Hr}-\mathrm{a} / \mathrm{Hc}$ : $5.5 \%)$ or zero ( $\mathrm{Hr}-\mathrm{a} / \mathrm{Hh}$ : $0 \%$ ) grafting success rate (Table 1 ). Thus, it was found that the $H$. heptaphyllus scion is efficient in grafting, especially if the rootstock is of the same species, also presenting an acceptable compatibility with $H$. roseo-albus.

In spite of the initial low grafting success rate of the Hh/Hc combination (55.5\%) (Table 1); it might be increased by the use of cell division inducers such as auxins: indole-3-butyric acid (IBA), naphthalene acid (NAA), indole-acetic acid (IAA), 2,4-dichlorophenoxyacetic acid (2,4-D) and 4-chlorophenoxyacetic acid (4-CPA). According to Yu et al. (2017), treatment with IAA $(10 \mu \mathrm{M})$ ensured a fivefold increase in the expression of CILAX1, -7, CIPIN3, $-4,-5,-6,-7$ and CIABCB4, genes related to the transport of auxins in watermelon shoots (Citrullus lanatus). Several authors claim that exogenous auxin is translocated in the plant in two ways. The first occurs by the movement between phloem cells. In the second, by transmembrane proteins, such as those of the AUX1 and LAX families that carry auxins from the extracellular to the intracellular environment (Petrásek \& Friml, 2009; Péret et al., 2012; Fábregas et al., 2015).

The low $(\mathrm{Hh} / \mathrm{Hr}-\mathrm{a})$ or null $(\mathrm{Hc} / \mathrm{Hh}, \mathrm{Hc} / \mathrm{Hr}-\mathrm{a}$ and $\mathrm{Hr}-\mathrm{a} / \mathrm{Hc})$ grafting success rates of the combinations among different species of Handroanthus (Table 1) is partially related to incompatibility between species due to the genetic difference, which can be confirmed by Collevatti et al. (2014), who observed high levels of polymorphism and genetic diversity in H. chrysotrichus, H. impetiginosus, H. roseo-albus and H. serratifolius. Similarly, Mori et al. (2012) found greater genetic diversity within than among $H$. heptaphyllus populations. Barbosa Filho et al. (2016) verified that the interspecific combination between Swietenia macrophylla (scion) and Khaya anthotheca (rootstock) was not compatible, whereas reciprocal grafting resulted in 52\% compatibility. According to these authors, the incompatibility may be associated with morphological, physiological and molecular modifications. The cell size of the two different parts (scion and rootstock) could be a limiting factor, as well as the exchange of liquids and metabolites between them.

The scion bud number did not differ statistically among the combinations: $\mathrm{Hc} / \mathrm{Hc}(1.33)$, $H r-a / H r-a(1.66)$ and $H h / H h$ (2.0) (self-graftings), $H h / H c(1.0)$ and $H h / H r-a(1.33)$. The largest scion bud growth rates occurred in the self-grafts $\mathrm{Hr}-\mathrm{a} / \mathrm{Hr}-\mathrm{a}(9.2 \mathrm{~cm}), \mathrm{Hc} / \mathrm{Hc}(7.3 \mathrm{~cm})$ and $\mathrm{Hh} / \mathrm{Hh}$ $(5.4 \mathrm{~cm}) . H$. heptaphyllus self-grafting was the one that presented the highest average values of the scion $(1.5 \mathrm{~cm})$, rootstocks $(1.5 \mathrm{~cm})$ and the grafted region diameters $(1.5 \mathrm{~cm})$, which for the $\mathrm{H} / \mathrm{H} h \mathrm{~h}$ combination were of the same average values. In the grafted region, the diameters in the combinations $\mathrm{Hc} / \mathrm{Hc}$ and $\mathrm{Hh} / \mathrm{Hc}(1.6 \mathrm{~cm})$ did not differ statistically from $\mathrm{Hh} / \mathrm{Hh}$ (Table 1).

The formation of a greater bud number in the self-grafted $H h$ (Table 1) might be explained by the higher grafting success rate, due to the well-established unions, which allow a more efficient flow of photo-assimilates for root growth, and water, nutrients and cytokinins (zeatin), responsible for inducing cell division in callus, in the presence of auxin (Taiz et al., 2017) for shoot growth. A large scion bud number is important for the canopy development. 
Table 1. Characteristics evaluated in grafting among the scion and rootstock combinations of the species of the genus Handroanthus.

\begin{tabular}{cccc}
\hline Scion/rootstock & Grafting success* (\%) & Scion bud number & Scion bud length (cm) \\
\hline$H c / H c$ & $33.3 \mathrm{c}^{(1)}$ & $1.3 \mathrm{a}$ & $7.3 \mathrm{~b}$ \\
$H c / H r-a$ & $5.5 \mathrm{~d}$ & $0.3 \mathrm{~b}$ & $0.1 \mathrm{e}$ \\
$H c / H h$ & $5.5 \mathrm{~d}$ & $0.3 \mathrm{~b}$ & $0.1 \mathrm{e}$ \\
$H r-a / H c$ & $5.5 \mathrm{~d}$ & $0.3 \mathrm{~b}$ & $0.1 \mathrm{e}$ \\
$H r-a / H r-a$ & $38.8 \mathrm{c}$ & $1.6 \mathrm{a}$ & $9.2 \mathrm{a}$ \\
$H r-a / H h$ & - & - & - \\
$H h / H c$ & $55.5 \mathrm{~b}$ & $1.0 \mathrm{a}$ & $1.8 \mathrm{~d}$ \\
$H h / H r-a$ & $27.7 \mathrm{c}$ & $1.3 \mathrm{a}$ & $2.1 \mathrm{~d}$ \\
$H h / H h$ & $83.3 \mathrm{a}$ & $2.0 \mathrm{a}$ & $5.4 \mathrm{c}$
\end{tabular}

\begin{tabular}{cccc} 
Scion/rootstock & Scion diameter $(\mathbf{c m})$ & Rootstock diameter $(\mathbf{c m})$ & Grafting region diam \\
\hline$H c / H c$ & $1.2 \mathrm{~b}$ & $1.0 \mathrm{~b}$ & $1.6 \mathrm{a}$ \\
$H c / H r-a$ & $0.1 \mathrm{~d}$ & $0.1 \mathrm{~d}$ & $0.1 \mathrm{c}$ \\
$\mathrm{Hc} / \mathrm{Hr}-\mathrm{a}$ & $0.1 \mathrm{~d}$ & $0.1 \mathrm{~d}$ & $0.1 \mathrm{c}$ \\
$H r-a / H c$ & $0.1 \mathrm{~d}$ & $0.1 \mathrm{~d}$ & $0.0 \mathrm{c}$ \\
$H r-a / H r-a$ & $1.1 \mathrm{~b}$ & $0.5 \mathrm{c}$ & $1.0 \mathrm{~b}$ \\
$H r-a / H h$ & - & - & - \\
$H h / H c$ & $1.0 \mathrm{~b}$ & $1.1 \mathrm{~b}$ & $1.6 \mathrm{a}$ \\
$H h / H r-a$ & $0.4 \mathrm{c}$ & $0.9 \mathrm{~b}$ & $0.5 \mathrm{c}$ \\
$H h / H h$ & $1.5 \mathrm{a}$ & $1.5 \mathrm{a}$ & $1.5 \mathrm{a}$
\end{tabular}

(1) Means followed by the same letter in the column, among scions $x$ rootstock combinations, belong to the same grouping, by Scott-Knott test for grouping means $(p<0.05)$. *Evaluations after 60 days of the experiment set up. Abbreviations: Hc (H. chrysotrichus); Hr-a (H. roseo-albus); Hh (H. heptaphyllus). The trace (-) observed in the combination $\mathrm{Hr}-\mathrm{a} / \mathrm{H} h \mathrm{~h}$ represents scion death.

The Hc scion-donor matrix presented the highest percentage of total lignin, followed by $\mathrm{Hh}$ and $\mathrm{Hr}-a(32.1,29.4$ and $28.4 \%$, respectively). The basic density followed the same pattern as lignin, that is, the $H c$ matrix presented the highest value $\left(0.69 \mathrm{~g} \mathrm{~cm}^{-3}\right)$ (Table 2).

In the present work, the low grafting success in the $\mathrm{Hc} / \mathrm{Hc}$ and $\mathrm{Hr}$ - $\mathrm{a} / \mathrm{Hr}$ - $\mathrm{a}$ self-graftings (Table 1) are due to the lower morphogenetic capacity of these species and the more advanced chronological age of the donor tree, which causes delay in the physiological process of tissue healing (scion/rootstock), allowing them to be susceptible to dehydration by exposure to adverse environmental conditions (high irradiance levels, high temperature and low relative humidity). Furthermore, the low grafting success can be explained by the percentage of total lignin in the tissues of donor trees, since high levels indicate that their cells have no longer biological function and only perform structural function in the plant (Table 2). According to Vanholme et al. (2010), lignified cells acquire hydrophobic properties, blocking the transport of water and dissolved nutrients into the cell. This is the reason why the lignification process usually coincides with cell senescence, resulting in tissues restricted to resistance and support functions.

Table 2. Lignin content, basic density and age of the scion-donor matrices of the genus Handroanthus.

\begin{tabular}{cccc}
\hline Species & Total lignin (\%) & Basic density $\left(\mathbf{g ~ c m}^{-\mathbf{3}}\right)$ & Age (years) \\
\hline$H C$ & 32.1 & 0.69 & 22 \\
$H h$ & 29.4 & 0.63 & 21 \\
$H r-a$ & 28.4 & 0.53 & 27 \\
\hline
\end{tabular}

In the Hh/Hh combination, the high percentage of grafting success (Table 1 ) probably occurs due to the increase in the healing speed of $H h$ tissues, which may be associated with 
its lower lignification and higher concentrations of cell division promoters (eg, auxins), fundamental in scion $x$ rootstock union. In vines, 3000 genes have been observed which transport mRNAs through scion junctions, genes encoding proteins involved in metabolism and signaling pathways of different plant hormones, including auxin, gibberellin, abscisic acid, ethylene and jasmonic acid (Yang et al., 2015).

Gas exchange was not statistically different among the non-grafted seedlings and the diverse graft combinations. The values for $A, g_{s}, E_{1} C_{i}$ and $C_{i} / C_{a}$ were low for the seed propagated species of Handroanthus and their graft combinations (Table 3). The non-grafted seedlings did not flower in the nursery, differently from the grafted plantlets in the $\mathrm{Hh} / \mathrm{Hh}$ (self-grafting) and $\mathrm{Hh} / \mathrm{Hc}$ combinations, which flowered after 120 days of grafting. It was observed that the combination $(H h / H c)$ resulted in fruit formation (Table 3 ).

Table 3 Photosynthesis - $A\left(\mu \mathrm{mol} \mathrm{CO}_{2} \mathrm{~m}^{-2} \mathrm{~s}^{-1}\right)$, stomatal conductance $-g_{\mathrm{s}}\left(\mathrm{mol} \mathrm{m} \mathrm{m}^{-2} \mathrm{~s}^{-1}\right)$, transpiration $E\left(\mathrm{mmol} \mathrm{H}_{2} \mathrm{O} \mathrm{m}^{-2} \mathrm{~s}^{-1}\right)$, internal/ambient carbon ratio $-C_{i} / C_{a}$, flowering and fruiting in ungrafted and grafted plantlets of species of the genus Handroanthus.

\begin{tabular}{|c|c|c|c|c|c|c|c|c|}
\hline \multicolumn{2}{|c|}{ Treatments } & $A^{*}$ & $g_{s}$ & $E$ & $C i$ & $\mathrm{Ci} / \mathrm{Ca}$ & Flower & Fruit \\
\hline \multicolumn{9}{|c|}{ (R) } \\
\hline \multirow{3}{*}{ 气 } & $H C$ & $4.137 a^{(1)}$ & $0.051 \mathrm{a}$ & $1.271 \mathrm{a}$ & $188.760 \mathrm{a}$ & $0.579 a$ & - & - \\
\hline & $H r-a$ & $4.055 \mathrm{a}$ & $0.051 \mathrm{a}$ & $1.242 \mathrm{a}$ & $215.523 \mathrm{a}$ & $0.549 a$ & - & - \\
\hline & $H h$ & $4.063 \mathrm{a}$ & $0.047 \mathrm{a}$ & $1.216 \mathrm{a}$ & $203.986 a$ & $0.563 a$ & - & - \\
\hline \multirow{10}{*}{ U } & (S/R) & & & & & & & \\
\hline & $\mathrm{Hc} / \mathrm{HC}$ & $3.744 \mathrm{a}$ & $0.052 \mathrm{a}$ & $1.230 \mathrm{a}$ & $194.247 a$ & $0.591 \mathrm{a}$ & - & - \\
\hline & $H c / H r-a$ & - & - & - & - & - & - & - \\
\hline & $\mathrm{Hc} / \mathrm{Hh}$ & - & - & - & - & - & - & - \\
\hline & $\mathrm{Hr}-\mathrm{a} / \mathrm{Hc}$ & - & - & - & - & - & - & - \\
\hline & $H r-a / H r-a$ & $4.008 \mathrm{a}$ & $0.050 \mathrm{a}$ & $1.264 \mathrm{a}$ & $213.558 \mathrm{a}$ & $0.604 \mathrm{a}$ & - & - \\
\hline & $H r-a / H h$ & - & - & - & - & - & - & - \\
\hline & $H h / H c$ & $4.108 \mathrm{a}$ & $0.047 \mathrm{a}$ & $1.263 \mathrm{a}$ & $183.485 \mathrm{a}$ & $0.548 \mathrm{a}$ & + & + \\
\hline & $\mathrm{Hh} / \mathrm{Hr}-\mathrm{a}$ & - & - & - & - & - & - & - \\
\hline & $H h / H h$ & $3.632 \mathrm{a}$ & $0.050 \mathrm{a}$ & $1.299 \mathrm{a}$ & $196.092 \mathrm{a}$ & $0.596 a$ & + & - \\
\hline
\end{tabular}

(1) Means followed by the same letter in the column, among non-grafted (US) and grafted seedlings (GS), in the scions $x$ rootstock combinations, belong to the same grouping, by Scott-Knott test for grouping means $(p<0.05)$. *Evaluations after 120 days of the experiment set up.

Top cleft grafting of $H$. heptaphyllus self-grafts, with scion and rootstocks of different diameters, resulted in the occurrence of an empty space between the parts, which was filled by a protuberance of greenish-colored cells (callusing). This is probably due to the degree of lignification of the scion tissues related to the age of the matrix plant, which results in a delay in the cell multiplication process. After 45 days, the emission of two buds was observed in the scion, suggesting the efficiency of the self-grafting process (Figure 2a). After 120 days of selfgrafting, flowering of the plantlets in the $\mathrm{Hh} / \mathrm{Hh}$ combination was observed (Figure $2 \mathrm{~b}$ ).

The high compatibility of $\mathrm{Hh}$ self-grafting makes it difficult to verify the boundaries between scion and rootstock tissues (dashed line in red) (Figure 2c), which is a positive situation. By means of internal tissue analyses, for example, the scanning and anatomy of the cross-section (Figure $2 \mathrm{~d}$ and $\mathrm{f}$, respectively) and longitudinal section (Figure $2 \mathrm{e}$ and $2 \mathrm{~g}$, respectively), it is possible to infer in more details the arrangement of the tissues.

However, seedlings of $\mathrm{Hh}$ seed origin of the same chronological age as the grafted seedlings did not flower (Figure 2h). Therefore, it is understood that the juvenile phase, that is, the chronological age and the physiological age, explain the early flowering of seedlings grafted in a nursery. The $\mathrm{Hh} / \mathrm{Hc}$ combination also flowered (Figure 2i) and even produced fruits (Figure 20). 


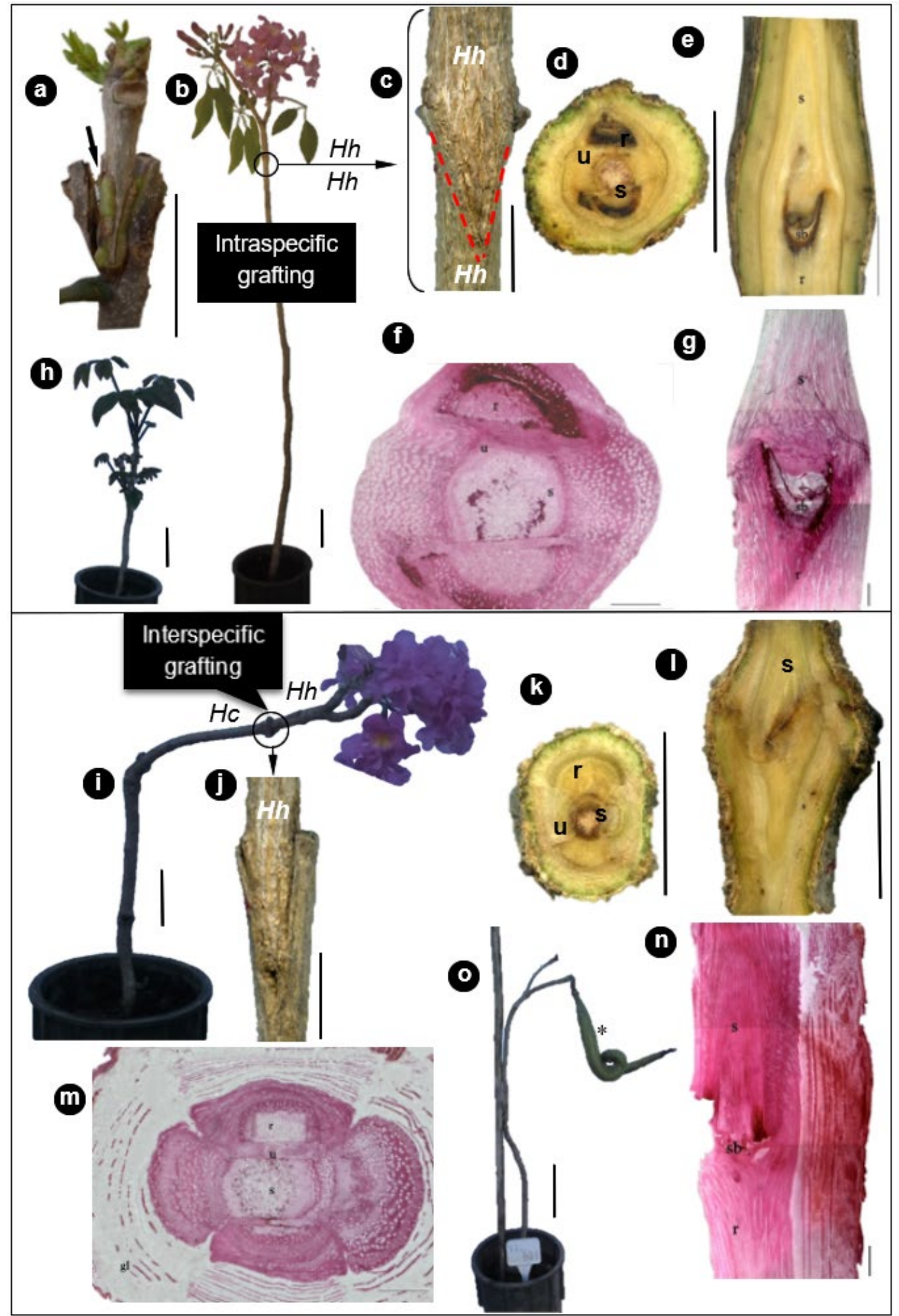

Figure 2. Top cleft grafting among species of the genus Handroanthus: (a) Scion and rootstock of a selfgrafted $H$. heptaphyllus plantlet (arrow indicating empty space between bionts). Bar: $5 \mathrm{~cm}$; (b) Flowering self-grafted plantlet after 120 days. (c-e) Detail of the self-grafted $H h$ region. (d) Cross-sectional and

(e) longitudinal scanning of the $\mathrm{Hh}$ self-grafted region (4800 dpi). (f) Anatomy of the cross and

(g) longitudinal section of $H h$ self-grafted region. (h) Hh seedling of non-flowering seminiferous propagation, with the same age as the self-grafted seedling. (i) Flowering $\mathrm{Hh} / \mathrm{Hc}$ grafted plantlet. Bar: $1 \mathrm{~cm}$. (j) Increase of $H h / H c$ grafted region. Bar: $1 \mathrm{~cm}$. (k) Scanning of the cross section of $H h / H c$ grafted region. (l) Section longitudinal of the $\mathrm{Hh} / \mathrm{Hc}$ grafted region (4800 dpi). (m) Anatomy of the cross section of $\mathrm{Hh} / \mathrm{Hr}$-a grafted region. (n) Anatomy of the longitudinal section of $\mathrm{Hh} / \mathrm{Hr}$-a grafted region. (o) Tutored plantlet $(H h / H c)$, leafless and with pod production (asterisk). Legend: $H c(H$. chrysotrichus); $H h$ (H. heptaphyllus), Circle (O): grafted region, s: scion, r: rootstock, sb: scion base, gl: growth layer and u: union between scion and rootstock. 
In the $H h / H c$ combination among different species, the stem tissues have their own characteristics in such a manner that the bark of $\mathrm{Hh}$ is thin and grayish brown, fissured longitudinally and decorticating in large plaques; while Hc has a grayish-thick bark and sparse and deep longitudinal fissures that facilitate the distinction between scion $(\mathrm{Hh})$ and rootstock (Hc species) (Figure 2j). Cross-sectional (Figure 2k) and longitudinal (Figure 2l) scanning aided to understand what happens to the union between two different species; however, the crosssectional anatomy (Figure $2 \mathrm{~m}$ ) made it possible to better verify the differentiated organization of the tissue, if compared to the longitudinal section (Figure $2 \mathrm{n}$ ).

There is a continuous connection between the scion and rootstock $(\mathrm{Hh} / \mathrm{Hh})$, formed by a group of parenchymal cells (callus). This connection is well consolidated; however, the secondary xylem tissues present greater uniformity in the region of the union (Figure $3 a$ ). In the $\mathrm{Hh} / \mathrm{Hc}$ combination, a rootstock connection is observed in the primary xylem, with predominance of parenchymal cells to the secondary xylem (Figure 3b), showing that the union between scion and rootstock xylem was not fully established, with the formation of new cell layers composing the new bark (Figure 3c).

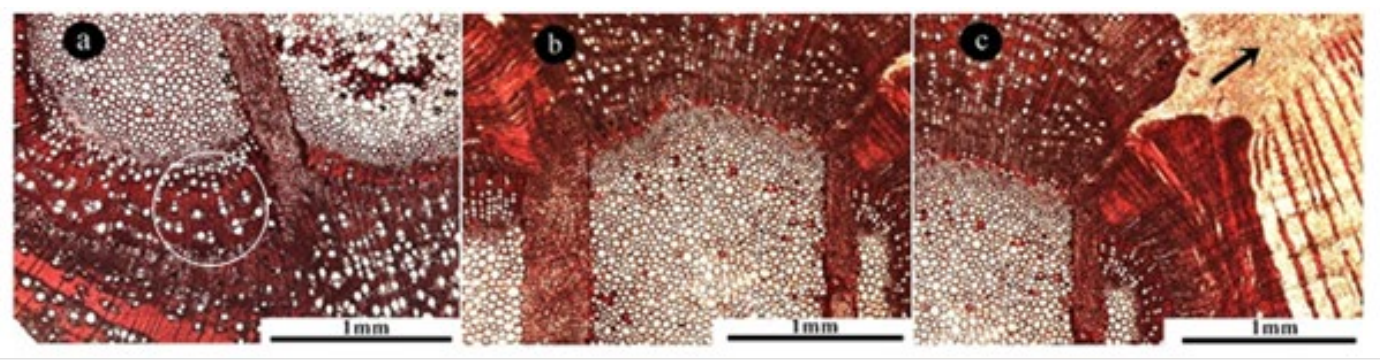

Figure 3. Morpho-anatomical analysis of the cross section of the grafted region observed under a microscope (ZEISS Axion Scope.A1). (a) Hh/Hh. Circle indicating the direction of the tissues advancing to the right and left in order to wrap the scion and rootstock, respectively. (b) Hh/Hc. (c) Detail of the connection of $\mathrm{Hh} / \mathrm{Hc}$ xylems. Arrow indicates direction of growth.

\section{CONCLUSIONS}

The high compatibility of $H$. heptaphyllus self-grafs results in early flowering. In the combination $\mathrm{Hh} / \mathrm{Hc}$, the flowering of $\mathrm{H}$. heptaphyllus occurs. The combination $\mathrm{H} h / \mathrm{Hh}$ has a wellestablished vascular connection between parts. The combinations $\mathrm{Hh} / \mathrm{Hc}$ and $\mathrm{Hr}-\mathrm{a} / \mathrm{Hr}-\mathrm{a}, \mathrm{Hc} / \mathrm{Hc}$ and $\mathrm{Hh} / \mathrm{Hr}$-a might potentially increase the grafting success. The combinations $\mathrm{Hc} / \mathrm{Hc}, \mathrm{Hh} / \mathrm{Hc}$, $\mathrm{Hr}-\mathrm{a} / \mathrm{Hr}$-a and $\mathrm{Hh} / \mathrm{Hh}$ demonstrate gas exchange values similar to those of the non-grafted seedlings of $\mathrm{Hc}, \mathrm{Hr}-\mathrm{a}$ and $\mathrm{Hh}$, which is a non-destructive physiological marker of the efficiency of the grafting process.

\section{ACKNOWLEDGMENTS}

To the National Council for Scientific and Technological Development (CNPq), for granting research scholarships to the first, second, fourth, sixth, seventh and ninth authors. To the Coordination for the Improvement of Higher Education Personnel (CAPES) for granting a research scholarship to the third author.

\section{REFERENCES}

Associação Brasileira de Normas Técnicas - ABNT. (2003). NBR-11941: madeira: determinação da densidade básica (6 p.). Rio de Janeiro: ABNT.

Backes, F. A. A. L., Girardi, L. B., Neuhaus, M., Bellé, R. A., Schwab, N. T., \& Peiter, M. X. (2011). Caracterização das espécies utilizadas na arborização urbana em Silveira Martins, RS. Revista Brasileira de Horticultura Ornamental, 17(2), 167-174. http://dx.doi.org/10.14295/rbho.v17i2.713.

Barbosa Filho, J., Carvalho, M. A. D., Oliveira, L. S., Konzen, E. R., Campos, W. F., \& Brondani, G. E. (2016) Propagation of Khaya anthotheca: interspecific grafting with Swietenia macrophylla and air layering. Cerne, 22(4), 475-484. http://dx.doi.org/10.1590/01047760201622042232. 
Brancalion, P. H. S., De Almeida, D. R. A., Vidal, E., Molin, P. G., Sontag, V. E., Souza, S. E. X. F., \& Schulze, M. D. (2018). Fake legal logging in the Brazilian Amazon. Science Advances, 4(8), eaat1192. PMid:30116781. http://dx.doi.org/10.1126/sciadv.aat1192.

Cardinal, Á. B. B., Gonçalves, P. S., \& Martins, A. L. M. (2007). Stock-scion interactions on growth and rubber yield of Hevea brasiliensis. Scientia Agrícola, 64(3), 235-240. http://dx.doi.org/10.1590/S010390162007000300004.

Collevatti, R. G., Estolano, R., Ribeiro, M. L., Rabelo, S. G., Lima, E. J., \& Munhoz, C. B. R. (2014). High genetic diversity and contrasting fine-scale spatial genetic structure in four seasonally dry tropical forest tree species. Plant Systematics and Evolution, 300(7), 1671-1681. http://dx.doi.org/10.1007/s00606-014-0993-0.

Cruz, C. D. (2016). Genes software: extended and integrated with the R, Matlab and Selegen. Acta Scientiarum. Agronomy, 38(4), 547-552. http://dx.doi.org/10.4025/actasciagron.v38i3.32629.

Fàbregas, N., Formosa-Jordan, P., Confraria, A., Siligato, R., Alonso, J. M., Swarup, R., Bennett, M. J., Mähönen, A. P., Caño-Delgado, A. I., \& Marta Ibañes, M. (2015). Auxin influx carriers control vascular patterning and xylem differentiation in Arabidopsis thaliana. PLOS Genetics, 11(4), e1005183. PMid:25922946. http://dx.doi.org/10.1371/journal.pgen.1005183.

Fuentes, I., Stegemann, S., Golczyk, H., Karcher, D., \& Bock, R. (2014). Horizontal genome transfer as an asexual path to the formation of new species. Nature, 511(7508), 232-235. PMid:24909992. http://dx.doi.org/10.1038/nature13291.

Goldschmidt, O. (1971). Ultraviolet spectra. In K. V. Sarkanen \& C. H. Ludwig (Eds.), Lignins: occurrence, formation, structure and reactions (pp. 241-298). New York: John Wiley \& Sons.

Gomide, J. L., \& Demuner, B. J. (1986). Determinação do teor de lignina em material lenhoso: método Klason modificado. O Papel, 47(8), 36-38.

Jardim Botânico do Rio de Janeiro - JBRJ. (2020). Handroanthus. In Jardim Botânico do Rio de Janeiro JBRJ (Ed.), Flora do Brasil 2020 em construção. Rio de Janeiro: JBRJ. Retrieved in 2020, January 21, from http://reflora.jbrj.gov.br/reflora/floradobrasil/FB114068

Jausoro, V., Llorente, B. E., \& Apóstolo, N. M. (2010). Structural differences between hyperhydric and normal in vitro shoots of Handroanthus impetiginosus (Mart. ex DC) Mattos (Bignoniaceae). Plant Cell, Tissue and Organ Culture, 101(2), 183-191. http://dx.doi.org/10.1007/s11240-010-9675-y.

Lima, P. R., Horbach, M. A., Dranski, J. A. L., Ecco, M., Malavasi, M. M., \& Malavasi, U. C. (2014). Avaliação morfofisiológica em mudas de Handroanthus impetiginosus (Mart. ex DC.) Mattos durante a rustificação. Floresta e Ambiente, 21(3), 316-326. http://dx.doi.org/10.1590/2179-8087.058813.

Martins, J. P. R., Santos, B. R., Barbosa, S., Máximo, W. P. F., Beijo, L. A., \& Paiva, R. (2011). Crescimento e aspectos sintomatológicos na aclimatização de ipê-roxo. Cerne, 17(4), 435-442. http://dx.doi.org/10.1590/S0104-77602011000400001.

Mori, N. T., Moraes, M. L. T., Morita, C. M., \& Mori, E. S. (2012). Genetic diversity between and within populations of Handroanthus heptaphyllus (Vell.) Mattos using microsatellite markers. Cerne, 18(1), 915. http://dx.doi.org/10.1590/S0104-77602012000100002.

Moro, M. F., \& Castro, A. S. F. (2015). A check list of plant species in the urban forestry of Fortaleza, Brazil: where are the native species in the country of megadiversity? Urban Ecosystems, 18(1), 47-71. http://dx.doi.org/10.1007/s11252-014-0380-1.

Oliveira, T. P. F., Barroso, D. G., Lamônica, K. R., \& Carvalho, G. C. M. W. (2016). Aplicação de AlB e tipo de miniestacas na produção de mudas de Handroanthus heptaphyllus Mattos. Ciência Florestal, 26(1), 313-320.

Péret, B., Swarup, K., Ferguson, A., Seth, M., Yang, Y., Dhondt, S., James, N., Casimiro, I., Perry, P., Syed, A., Yang, H., Reemmer, J., Venison, E., Howells, C., Perez-Amador, M. A., Yun, J., Alonso, J., Beemster, G. T., Laplaze, L., Murphy, A., Bennett, M. J., Nielsen, E., \& Swarup, R. (2012). AUX/LAX genes encode a family of auxin influx transporters that perform distinct functions during Arabidopsis development. The Plant Cell, 24(7), 2874-2885. PMid:22773749. http://dx.doi.org/10.1105/tpc.112.097766.

Perez, J., Eigenbrode, S. D., Hilje, L., Tripepi, R. R., Aguilar, M. E., \& Mesen, F. (2010). Use of grafting to prevent Hypsipyla grandella (Zeller) (Lepidoptera: Pyralidae) damage to new world Meliaceae species. Neotropical Entomology, 39(4), 618-625. PMid:20878001. http://dx.doi.org/10.1590/S1519$566 \times 2010000400024$.

Petrásek, J., \& Friml, J. (2009). Auxin transport routes in plant development. Development, 136(16), 2675 2688. PMid:19633168. http://dx.doi.org/10.1242/dev.030353. 
Santos, A. R., Rocha, C. F. D., \& Bergallo, H. G. (2010). Native and exotic species in the urban landscape of the city of Rio de Janeiro, Brazil: density, richness, and arboreal deficit. Urban Ecosystems, 13(2), 209-222. http://dx.doi.org/10.1007/s11252-009-0113-z.

Taiz, L., Zeiger, E., Møller, I. M., \& Murphy, A. (2017). Fisiologia e desenvolvimento vegetal (6. ed., 858 p.). Porto Alegre: Artmed.

Vanholme, R., Demedts, B., Morreel, K., Ralph, J., \& Boerjan, W. (2010). Lignin biosynthesis and structure. Plant Physiology, 153(3), 895-905. PMid:20472751. http://dx.doi.org/10.1104/pp.110.155119.

Wendling, I., \& Xavier, A. (2001). Gradiente de maturação e rejuvenescimento aplicado em espécies florestais. Floresta e Ambiente, 8(1), 187-194.

Yang, Y., Mao, L., Jittayasothorn, Y., Kang, Y., Jiao, C., Fei, Z., \& Zhong, G.-Y. (2015). Messenger RNA exchange between scions and rootstocks in grafted grapevines. BMC Plant Biology, 15(1), 251. PMid:26480945. http://dx.doi.org/10.1186/s12870-015-0626-y.

Yu, C., Dong, W., Zhan, Y., Huang, Z.-A., Li, Z., Kim, S., \& Zhang, C. (2017). Genome-wide identification and expression analysis of CILAX, CIPIN and CIABCB genes families in Citrullus lanatus under various abiotic stresses and grafting. BMC Genetics, 18(1), 33. PMid:28388893. http://dx.doi.org/10.1186/s12863-017-0500-z.

Authors' contributions: IMS: Conceptualization, data curation, investigation, methodology, project administration, validation, visualization, writing - original draft; RSA: Conceptualization, data curation, funding acquisition - investigation, methodology, project administration, resources, supervision, validation, visualization, writing - original draft; TLMR and RGM: Investigation, writing - review \& editing; ERS: Formal analysis, writing review \& editing; JTSO and JCL: Investigation, writing - review \& editing; JPBO: Software, writing - review \& editing; AF: Formal analysis, writing - review \& editing; WCO: Writing - review \& editing. 